\title{
Analysis by Coagglutination of the Distribution of a 24,000-Dalton Surface Protein in Yersinia Isolates
}

\author{
J. TOYOS, R. DÍAZ,* E. URRA, AND I. MORIYÓN \\ Departamento Interfacultativo de Microbiología y Parasitología, Universidad de Navarra, 31080 Pamplona, Spain
}

Received 12 November 1985/Accepted 6 January 1986

\begin{abstract}
The presence of a 24,000-dalton surface protein in 215 isolates of Yersinia enterocolitica and related species was examined. By coagglutination with the specific antiserum, a $100 \%$ correlation with the pathogenic biogroups was found. Thus, this method is useful for the rapid screening of potential pathogenic $Y$. enterocolitica isolates.
\end{abstract}

Recently, we have shown that representative strains of the pathogenic serogroups of Yersinia enterocolitica but not of the avirulent serogroups or other species of Yersinia synthesize a 24,000-dalton ( $\mathrm{Da}$ ) plasmid-independent protein when grown on a solid medium at $37^{\circ} \mathrm{C}$ with a metabolizable carbohydrate (2). This protein behaves as a surface antigen, but it is not a membrane protein and remains only loosely attached to the cell (2). In the present study, we have extended those findings by examining whether the $24,000-\mathrm{Da}$ protein is synthesized only by strains associated with enterocolitis.

To test this hypothesis, 215 strains of $Y$. enterocolitica and related species from human, animal, and environmental sources (Table 1) were examined by coagglutination with antiserum specific for the 24,000 -Da protein. The staphylococci were prepared and sensitized with the 24,000-Da antiserum as described by Kronvall (4). The preparation of the antiserum has been described previously (2); as tested by Western blot and immunoelectrophoresis, it contained antibodies to the 24,000 -Da protein but not to other surface or cytoplasmic antigens. For coagglutination, duplicates of each isolate were inoculated either in Trypticase soy agar (BBL Microbiology Systems) or in the same medium supplemented with $0.25 \%$ glucose and $0.25 \%$ sucrose and grown for $24 \mathrm{~h}$ at $37^{\circ} \mathrm{C}$.

The results showed that when grown without sugars, none of the 215 strains was coagglutination positive. On the other hand, when grown on the medium supplemented with sugars, some strains were coagglutination positive, the precise result depending upon the serogroup and the origin (Table 1). Of 182 human strains, 162 were coagglutination positive and thus expressed the 24,000-Da protein; all these 162 strains belonged to the serogroups associated with enterocolitis. In contrast, all the coagglutination-negative strains of human origin belonged to either biogroup 1 (esculin positive and nonpathogenic) or to other species of Yersinia.

The coagglutination test with the animal and environmental strains confirmed these results. Only one strain synthesized the 24,000-Da protein. It is noteworthy that this strain (B2576) was originally isolated from a monkey, that it belongs to serogroup $\mathrm{O}: 13,7$, and that it is virulent (1).

Altogether, the data presented in this report confirm our previous finding of the necessity of a metabolizable sugar for the expression of the $24,000-\mathrm{Da}$ protein. Moreover, they

\footnotetext{
* Corresponding author.
}

TABLE 1. Results of the coagglutination with the anti-24,000-Da protein serum in 215 Yersinia isolates

\begin{tabular}{|c|c|c|c|}
\hline \multirow[t]{2}{*}{ Yersinia species } & \multicolumn{2}{|c|}{$\begin{array}{l}\text { Coaggluti- } \\
\text { nation }\end{array}$} & \multirow[t]{2}{*}{ Serogroup (no. of strains) } \\
\hline & + & - & \\
\hline \multicolumn{4}{|l|}{ Human origin } \\
\hline$Y$. enterocolitica & 162 & 0 & $\begin{array}{l}\text { O:3 (145); O:4,32; O:5,27 } \\
\text { Biog 2; O:8 (5); O:9 (3); } \\
\text { O:13,18 (2); O:13a,13b } \\
\text { (4); O:21 }\end{array}$ \\
\hline$Y$. enterocolitica & 0 & 14 & $\begin{array}{l}\text { O:1,6; O:5 (5); O:5,27 } \\
\quad \text { Biog } 1(2) ; O: 7,8(4) \\
\text { O:7,8,13,19; O:13 }\end{array}$ \\
\hline Y. frederiksenii & 0 & 4 & $O: 3(2) ; 0: 4,10,14,16 ; 0: 16$ \\
\hline$Y$. intermedia & 0 & 1 & $0: 3,37$ \\
\hline$Y$. kristensenii & 0 & 1 & $0: 11$ \\
\hline \multicolumn{4}{|c|}{$\begin{array}{l}\text { Environmental and animal } \\
\text { origin } \\
Y \text {. enterocolitica }\end{array}$} \\
\hline Cow & 0 & 6 & $\begin{array}{l}\text { O:5,27 (2); O:6,30 (3); } \\
\text { O:7,8 }\end{array}$ \\
\hline Water & 0 & 21 & $\begin{array}{l}\mathrm{O}: 5(8) ; \mathrm{O}: 6(12) ; \\
\quad \mathrm{O}: 7,8,13,19(11)\end{array}$ \\
\hline Monkey & 1 & 0 & $0: 13,7$ \\
\hline $\begin{array}{l}Y . \text { frederiksenii } \\
\text { Water }\end{array}$ & 0 & 1 & Nontypeable \\
\hline \multicolumn{4}{|l|}{$Y$. intermedia } \\
\hline Water & 0 & 2 & $0: 16,11 ; 0: 17$ \\
\hline Sheep & 0 & 1 & $0: 12$ \\
\hline \multicolumn{4}{|l|}{ Y. kristensenii } \\
\hline Water & 0 & 1 & $0: 11$ \\
\hline
\end{tabular}

show that $100 \%$ of the $Y$. enterocolitica strains belonging to the clinically significant serogroups synthesized the 24,000-Da protein and that none of the clinically irrelevant strains produced this antigen. Thus, we conclude that although plasmid independent (2), the 24,000 -Da protein behaves as a pathogenicity marker.

Recently, it has been shown that the pyrazinamidase activity relates to virulence (3). Coagglutination with serum specific to the $24,000-\mathrm{Da}$ protein provides another rapid method for distinguishing potential pathogenic from nonpathogenic strains in epidemiological surveys.

We thank J. M. Alonso, M. Alvarez, P. Ahvonen, C. G. Aulisio, E. J. Bottone, J. Bruce, I. Dorronsoro, M. P. Doyle, E. Perez- 
Trallero, G. Prats, C. O. Tacket, and G. Wauters for providing some of the strains used in this work.

Fellowship support to J. Toyos from the Associación de Amigos de la Universidad de Navarra is also gratefully acknowledged.

\section{LITERATURE CITED}

1. Aulisio, C. C. G., W. E. Hill, J. T. Stanfield, and R. L. Sellers, Jr. 1983. Evaluation of virulence factor testing and characteristics of pathogenicity in Yersinia enterocolitica. Infect. Immun. 40:
330-335.

2. Díaz, R., E. Urra, J. Toyos, and I. Moriyon. 1985. Characterization of a Yersinia enterocolitica antigen common to enterocolitisassociated serotypes. J. Clin. Microbiol. 22:1035-1039.

3. Kandolo, K., and G. Wauters. 1985. Pyrazinamidase activity in Yersinia enterocolitica and related organisms. J. Clin. Microbiol. 21:980-982.

4. Kronvall, G. 1973. A rapid slide-agglutination method for typing pneumococci by means of specific antibody adsorbed to protein A-containing staphylococci. J. Med. Microbiol. 6:187-190. 